\title{
Halshuggning med bila
}

Några rättshistoriska randanteckningar.

Av advokat WILH. PENSER, Eslöv

I en artikel i NTfK „Den sista avrättningen i Danmark“"1) har Klas Lithner lämnat vissa tillrättalägganden av vad som förekommit i samband med exekverandet av olika dödsdomar i Danmark och framförallt korrigerat utländska felkällor. I detta sammanhang omnämner Lithner händelseförloppet vid den näst sista avrättningen i Danmark den 22 november 1882 av Anders Nielsen, kallad Sjællænder. Bödeln lyckades först med det tredje hugget hugga av delinkventens huvud. Lithner fortsätter: „Då avrättningen var offentlig, uppstod det allmän kritik. Enligt Justitiedepartementets officiella utredning hade bödeln visserligen halkat på marken, men hade icke varit berusad, och Nielsen hade dött av det första hugget".

Bland argumenten på sin tid för avskaffande av dödsstraffet var bl. a. den tekniskt otillfredsställande metoden att avrätta med bila. Det skakande händelseförloppet vid Nielsen-Sjællænders avrättning är icke unikt. När det gäller svenska förhållanden må erinras om en av Knut Olivecrona lämnat redogörelse för en särskilt makaber avrättning: ${ }^{2}$ )

,År 1853 afrättades å Pukaviks afrättsplats mördaren Pelle Bollman. Han nedlades motsträfvigt på stupstocken. Skarprättarens bila träffade i stället för halsen snedt över ena skuldran. Med ett vrålande anskri kastade sig delinqventen våldsamt om, så att ansigtet kom uppåt. Det andra hugget träffade icke heller rätt ställe, utan till en del snedt öfver den nedre delen av hufvudet eller ansigtet, och först för det tredje hugget skiljdes hufvudet från kroppen.“" ${ }^{3}$ )

Det må här i korthet nämnas, att båtsmannen Håkan Jönsson Bollman, som fått tillfälligt arbete hos bonden Sven Olsson i Farabol i Kyrkhults socken och dennes unga hustru Bengta, i samråd med Bengta förgiftade Sven Olsson och ett av makarnas barn med arsenik. Även Bengta dömdes till döden och avrättades samtidigt med Bollman. ${ }^{4}$ )

1) NTfK 1971, sid. 336--339.

2) Knut Olivecrona: Om dödsstraffet, 2: dra uppl. 1891, sid. 243.

3) Olivecrona har bl. a. misstagit sig om tiden. Avrättningen ägde rum den 20 januari 1854 på avrättsplatsen i Norje (vid Pukavik) i Blekinge. Se min artikel: „Listers härads avrättsplats i Norje och den sista exekutionen därstädes" (i Årsbok för Blekinge, årg. 1944, sid. $74-89$ ).

4) Inom parentes må erinras om att denna art av brott är vanlig $i$ tiden. Lithner nämner den till döden år 1872 dömde Hans Rasmusson, vars brott „,bestod $\mathrm{i}$ att han, som tjänade dräng hos en lantbrukare och hade ett förhållande med dennes hustru, i samråd med denna mördat mannen." 
Medan Nielsen-Sjællænders avrättning ansågs så uppseendeväckande, att den föranledde en särskild utredning från Justitiedepartementet, tycks avrättningen av Bollman har fått passera opåtalat. Bollman dömdes till döden enligt Högsta Domstolens utslag den 3 november 1853, och utslaget expedierades till Konungens Befallningshavare i Blekinge län den 1 december 1854. I brevdiariet där står dock antecknat, att utslaget efter avrättningen återkom dit med anmälan att ,förrättningen ej gick bra“.

Kvar står Knut Olivecronas reflexion, att dödsstraffet är av en svårt demoraliserande verkan, om det någon gång inträffar „hvilket tyvärr ingalunda är sällsynt, att skarprättaren icke förmår i ett hugg beröfva delinkventen lifvet". Nu låg det närmare 30 år mellan Nielsen-Sjællænders och Bollmans avrättningar; vid den senare tidpunkten uppmärksammades förvisso en avrättning $i$ högre grad än vid den förra.

Ett intressant påpekande görs i Justitiedepartementets utredning angående omständigheterna vid Nielsen-Sjællænders avrättning; bödeln hade icke varit berusad.

Det synes antagligt, att skarprättaren vanligtvis styrkte sig med spritdrycker inför sitt blodiga värv.

Hur det förhöll sig med skarprättarens nykterhet vid Bollmans avrättning undandrager sig bedömande, men man må kanske befara att därmed var si och så. Enligt en bevarad muntlig tradition $^{5}$ ) skulle skarprättaren efter avrättningen ha sagt, att han såg tre huvuden, när han skulle hugga, och han visste inte vilket han skulle hugga på. Det var orsaken till att huggen misslyckades. Om vad här återgivits är riktigt, må det underbygga en teori om spritpåverkan hos skarprättaren.

För en av de sista avrättningarna i Sverige, avrättningen av Yngsjömörderskan Anna Månsdotter på fängelset i Kristianstad den 7 augusti 1890, finns en autentisk berättelse av en dansk journalist Peter Nansen. ${ }^{6}$ ) Här uppträder en skarprättare, som utför sin första exekution, Han lyckades såtillvida med denna, att delinkventens huvud föll för första hugget, låt vara att detta hugg träffade delinkventen alldeles under öronen och snett framåt, så att hakan och en del av tungan hade blivit kvar vid kroppen. Frågan om skarprättarens nykterhet var tydligen aktuell även i detta fall. Före exekutionen tillfrågades skarprättaren härom; han förklarade, att han var godtemplare.

Wilh. Penser.

$\left.{ }^{5}\right)$ Uppteckning i Lunds universitets folkminnesarkiv (M.4.715, sid. 46 o.ff).

$\left.{ }^{6}\right)$ Uppteckningen är återgiven av Yngve Lyttkens, Yngsjömordet, sid, $181-190$. 